\title{
OPEN Shelf-life, quality, safety evaluations of blueberry fruits coated with chitosan nano-material films
}

\begin{abstract}
Yang $\mathrm{Li}^{1 \bowtie}$, Sami Rokayya ${ }^{2,3 凶}$, Fuguo $\mathrm{Jia}^{3 凶}, \mathrm{Xin} \mathrm{Nie}^{1}$, Jingwen $\mathrm{Xu}^{1}$, Abeer Elhakem ${ }^{4}$, Manal Almatrafi, ${ }^{2,5}$, Nada Benajiba ${ }^{6} \&$ Mahmoud Helal $^{7,8}$

Chitosan coating $(\mathrm{B} / \mathrm{CH})$ in addition with nano-material films as silicon $\left(\mathrm{B} / \mathrm{CH} / \mathrm{Nano}-\mathrm{SiO}_{2}\right)$ and titanium $\left(\mathrm{B} / \mathrm{CH} / \mathrm{Nano}-\mathrm{TiO}_{2}\right)$ dioxides were developed and applied to detect potential changes on fresh blueberry fruits in commercial storage temperature. Physical, mechanical parameters (weight loss, decay rate, colour index and firmness), phytochemical contents (ascorbic acid, acidity, soluble solids concentration, titratable acidity, and repining index), phenolic enzymes (peroxidase and polyphenoloxidase), pigments (anthocyanin) and microbiological analysis (mesophilic aerobic, yeasts and molds populations) were detected every other day until the end of the experiment.

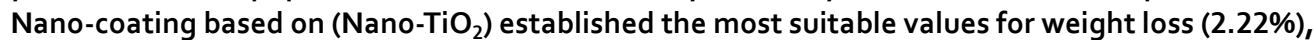
titratable acidity $\left(0.45 \%\right.$ citric acid), and repining index. $\left(\mathrm{B} / \mathrm{CH} / \mathrm{Nano}-\mathrm{TiO}_{2}\right)$ reported a gradual increase in polyphenoloxidase and peroxidase enzyme activities $(659.45 \mathrm{U} / \mathrm{min} \mathrm{g})$ and $(20.39 \mathrm{U} / \mathrm{min} \mathrm{g})$, respectively. While, $\left(\mathrm{B} / \mathrm{CH} / \mathrm{Nano}-\mathrm{SiO}_{2}\right)$ established the slightest change in acidity (2.61), anthocyanin (105.19 cyanidin-3-O-glucoside $\mathrm{mg} / 100 \mathrm{~g} \mathrm{FW}$ ) and minimized the growth of mesophilic aerobic, yeasts, and molds populations (3.73-3.98 log $\mathrm{CFU} / \mathrm{g})$, respectively. $(\mathrm{B} / \mathrm{CH})$ films maintained lightness (6.80\% loss) and recorded the highest ascorbic acid content ( $7.34 \mathrm{~g} / 100 \mathrm{~g} \mathrm{FW})$. Therefore, chitosan nano-material films can maintain nutrients and control the microbial growth for extending the shelf life of fresh blueberry fruits.
\end{abstract}

Blueberry fruit (Vacciniumashei L.) is one of the main potential functional food which can act as anticarcinogenic and has therapeutic properties due to the presence of bioactive components such as anthocyanin and phenolics ${ }^{1}$. Blueberries have plenty of essential nutrients such as vitamins ( $\mathrm{A}, \mathrm{B}, \mathrm{C}$, and $\mathrm{K})$, minerals ( $\mathrm{P}, \mathrm{Mg}, \mathrm{Fe}, \mathrm{Ca}, \mathrm{K}, \mathrm{Mn})$, and low levels of fats and sodium. Blueberries have an essential role in preventing bone loss, protecting the liver, atherosclerosis, anticarcinogenic, antihypertensive, hypoglycemic, and regulate the inflammatory responses ${ }^{2}$. Although blueberry fruit is considered as a very perishable fruit as the proper storage condition is approximately $4{ }^{\circ} \mathrm{C}$, with a relative humidity of (90-95\%) which costs the producers plenty of money and space to guarantee the fruit quality and avoid any sight of spoilage ${ }^{3}$. Several studies showed that edible coatings had improved the shelf-life and protect from the external environmental influences, such as chitosan, starch, pectin, alginate, pullulan, quinoa protein, and sunflower oil during room temperature ${ }^{4,5}$. In addition, other studies focused on the effect of chilling on blueberries preservation ${ }^{6,7}$. Various preservation technologies have been applied in fresh blueberries such as gamma irradiation, ozonation, chlorine oxidase, and some sanitizers (captan, difolatan, hexanal, and vinegar vapors $)^{8}$. Recently, there is an increasing interest in nano-films applications or coatings in

\footnotetext{
${ }^{1}$ College of Food Science, Northeast Agricultural University, Harbin 150030, Heilongjiang, China. ${ }^{2}$ Department of Food Science and Nutrition, College of Sciences, Taif University, P.O. 11099, Taif 21944, Saudi Arabia. ${ }^{3}$ College of Engineering, Northeast Agricultural University, Harbin 150030, Heilongjiang, China. " Department of Biology, College of Science and Humanities in Al-Kharj, Prince Sattam Bin Abdulaziz University, Al-Kharj 11942, Saudi Arabia. ${ }^{5}$ Department of Nutritional Sciences, University of Connecticut, Storrs, CT 06269, USA. ${ }^{6}$ Department of Basic Health Sciences, Deanship of Preparatory Year, Princess Nourah Bint Abdulrahman University, P.O. Box 84428, Riyadh 11671, Saudi Arabia. ${ }^{7}$ Department of Mechanical Engineering, Faculty of Engineering, Taif University, P.O. 11099, Taif 21944, Saudi Arabia. ${ }^{8}$ Production and Mechanical Design Department, Faculty of Engineering, Mansoura University, Mansoura 35516,Egypt. ${ }^{\circledR}$ email: yangli@neau.edu.cn; rokayya.d@tu.edu.sa; jiafg301@neau.edu.cn
} 


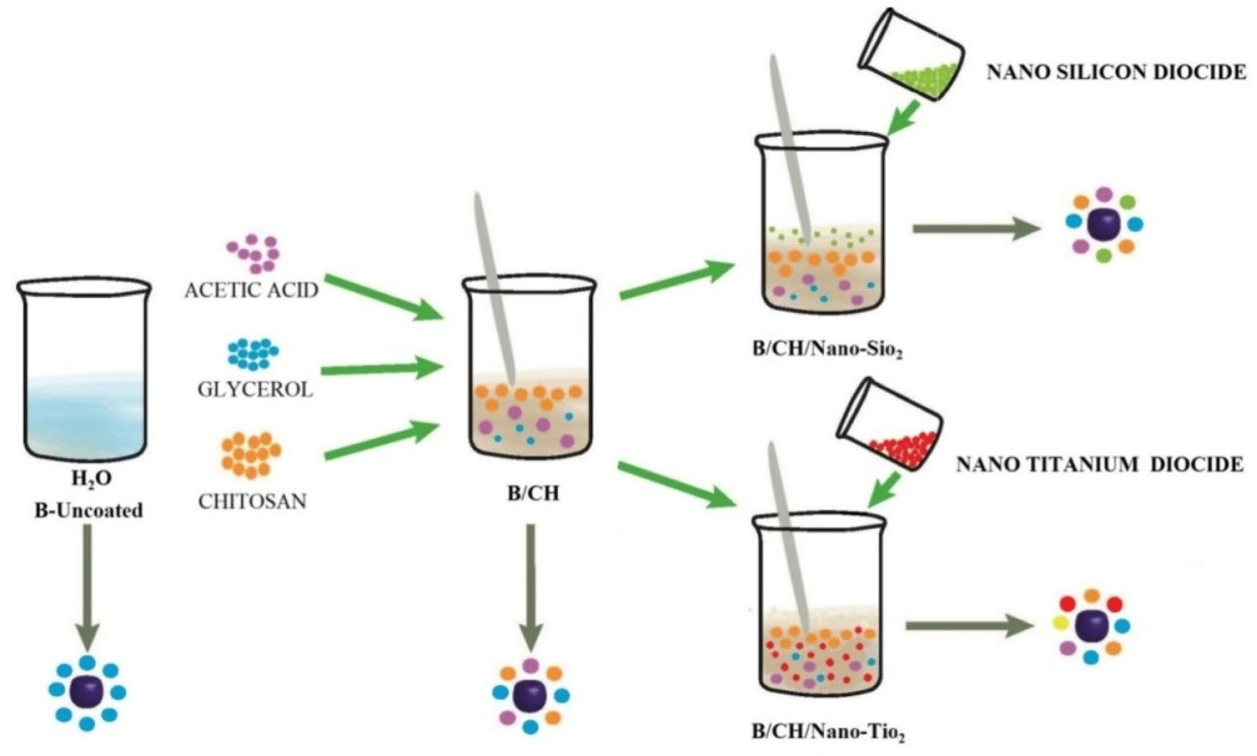

Figure 1. Films preparation.

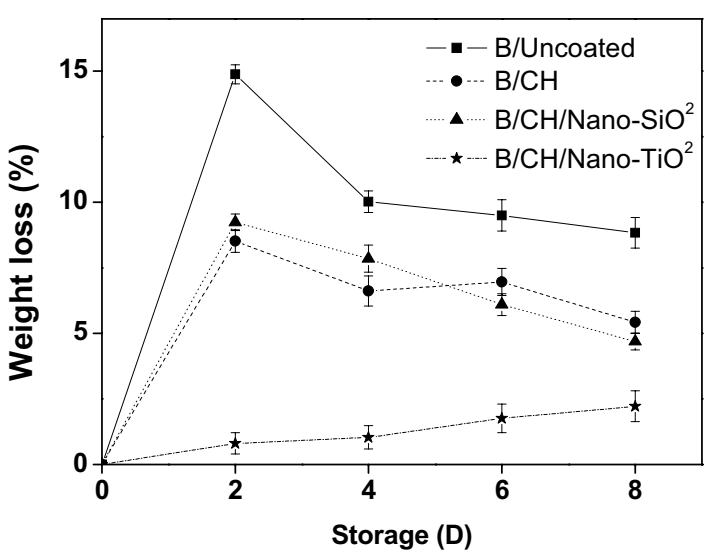

a

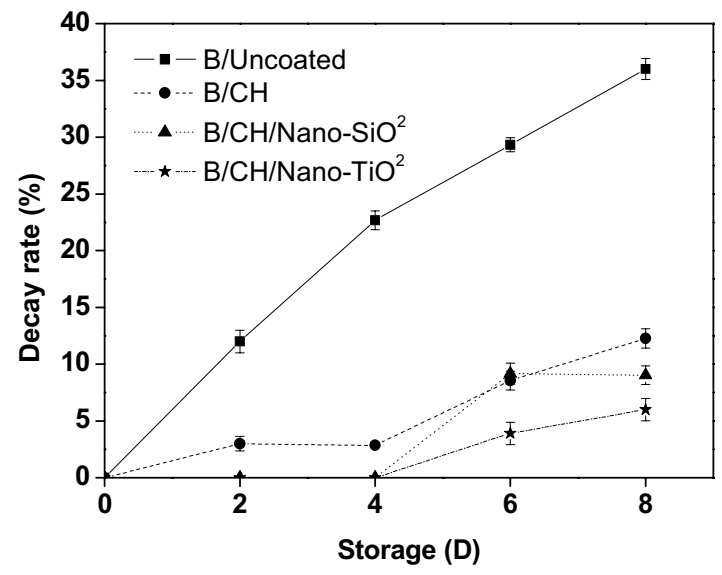

b

Figure 2. Effects of coating films on weight loss (a) and (b) decay rate.

food technology to extend the shelf-life and produce low-pH fresh vegetables and fruits ${ }^{9}$. Nearly, half percent of the postharvest blueberries are inconsumable due to loss of texture, weight, quality deterioration, and/or microbial growth, especially due to molds and fungal outbreaks (e.g., Botrytis cinerea) ${ }^{10}$. Nano-films are defined as a very thin layer, less than $100 \mathrm{~nm}$ that can be used as a coating layer over the fruit or as an external film to control dehydration, shelf-life limitation, polyphenolics oxidation, transpiration, enzymes, respiration, exposure to oxygen and light, microbial attack to achieve the consumer acceptability ${ }^{11}$. Coatings can provide pre-washed or even ready-to-eat blueberries as new products in supermarkets ${ }^{12}$.

The aim of this research work was to describe the effects of chitosan, titanium, and silicon dioxide nanoparticles coating films (in-vitro and in-vivo) on fresh blueberries samples to evaluate the postharvest quality prolong shelf lifeduring commercial storage for outlook industrialized development.

\section{Results}

Weight loss and decay rate. In general, Fig. 1 shows the films preparations, there was high weight loss in all the coated blueberries after the whole storage period (Fig. 2a). B/CH/Nano- $\mathrm{TiO}_{2}$ coated treatment significantly established reduced weight loss $(2.22 \%)$ compared to $\mathrm{B} / \mathrm{CH}$ and $\mathrm{B} / \mathrm{CH} / \mathrm{Nano}-\mathrm{SiO}_{2}$ coated samples ( 5.43 and $4.69 \%$, respectively). Though, the maximum loss was achieved by B/Uncoated blueberry samples was $(8.83 \%)$. 


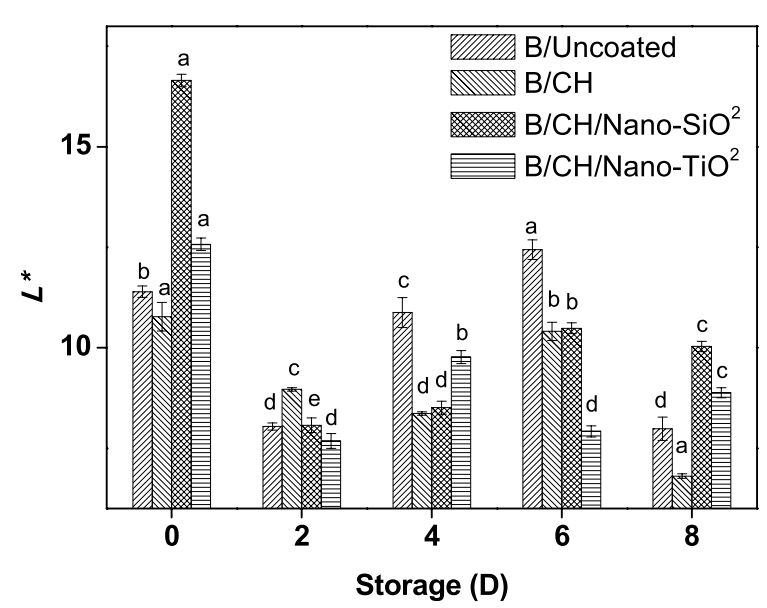

a

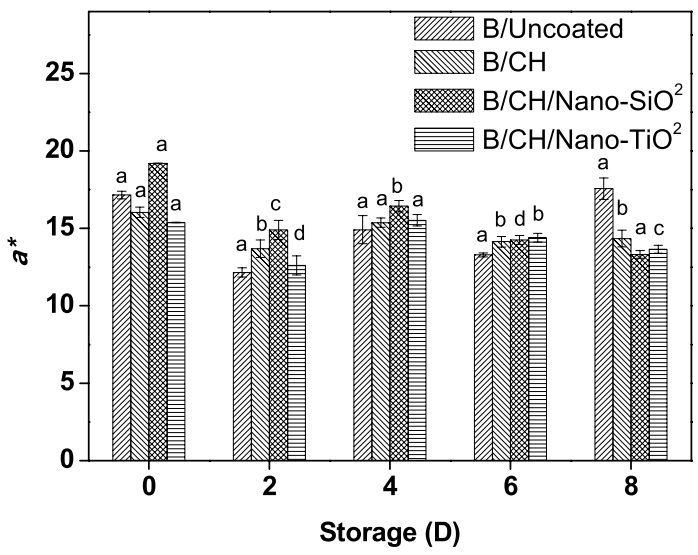

b

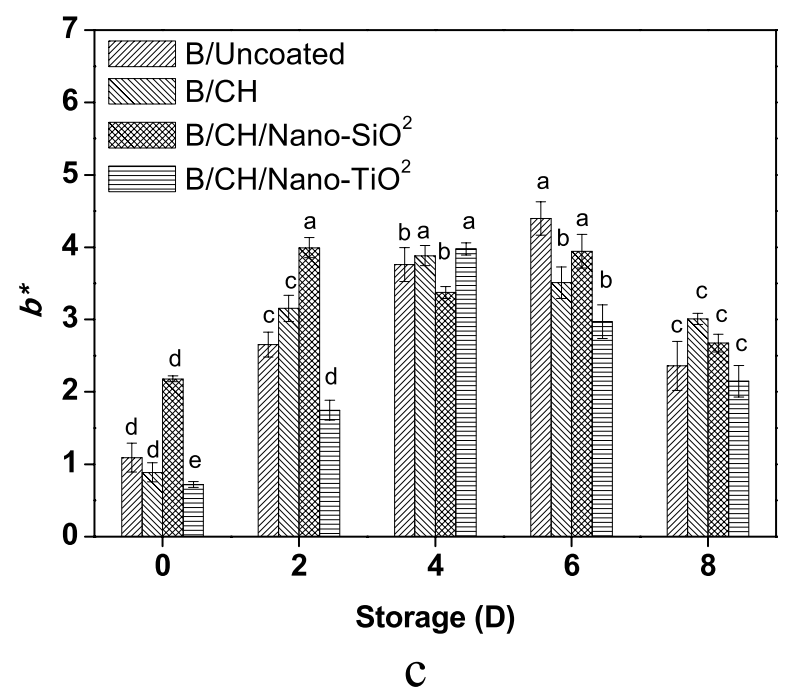

Figure 3. Effects of coating films on colour index $L^{\star}(\mathbf{a}), a^{\star}(\mathbf{b})$ and $b^{\star}(\mathbf{c})$.

$\left(\mathrm{B} / \mathrm{CH} / \mathrm{Nano}-\mathrm{TiO}_{2}\right)$ followed by $\left(\mathrm{B} / \mathrm{CH} / \mathrm{Nano}-\mathrm{SiO}_{2}\right)$ coating treatments controlled decay rates $(5.99-9.04 \%)$ on the 8th day at the ambient temperature, Fig. 2b. Karolina et al. ${ }^{13}$, established comparable results for fresh Highbush blueberry.

Colour index and firmness texture analysis. In terms of the colorimetric coordinates during the whole storage. Though, on the 6th day, lightness values were similar to each other compared with (B/Uncoated), Fig. 3a. Enzymatic processes and weight loss could be the main reasons for the visual quality reduction. $(\mathrm{B} / \mathrm{CH})$ coating maintained lightness $(6.80 \%$ loss) as compared to other nano-coatings, whereas (B/Uncoated) samples reported the maximum $(7.98 \%$ loss $)$.

$\left(a^{*}\right)$ values were decreased until the second day of the whole storage period then began to increase, Fig. $3 \mathrm{~b}$. Both $\left(\mathrm{B} / \mathrm{CH} / \mathrm{Nano}-\mathrm{SiO}_{2}\right)$ followed by $\left(\mathrm{B} / \mathrm{CH} / \mathrm{Nano}-\mathrm{TiO}_{2}\right)$ coated blueberry samples reported lower values against the (B/Uncoated), (13.31\%, 13.65-17.57\% loss) at the end of the storage period, respectively.

The epidermis of blueberries was characterized such as violet, though differences among various coating films treatment occurred during 8 days. $\left(\mathrm{B} / \mathrm{CH} / \mathrm{Nano}-\mathrm{TiO}_{2}\right)$ coating treatment $(2.97 \%$ loss $)$ exhibited lower $b^{*}$ values beginning from the 6 th day against the (B/Uncoated) samples (4.40\% loss), Fig. 3c.

The result reported that various coating films and storage time had effected on the firmness of blueberry samples, which decreased with the increasing time, Table 1 . By 8 th day, $\left(\mathrm{B} / \mathrm{CH} / \mathrm{Nano}-\mathrm{TiO}_{2}\right)$ coating film retained the greatest firmness (9.03 $\mathrm{N} \mathrm{m}^{-1}$ loss); whereas, (B/Uncoated) samples recorded the lowest firmness $\left(18.09 \mathrm{~N} \mathrm{~m}^{-1}\right.$ loss). Mannozzi et al. ${ }^{1}$, established similar firmness results of coated blueberries samples due to the berry skin inflexibility.

Phytochemical changes. Various coating films preserved the ascorbic acid content as shown in (Fig. 4a). On the 8th day, (B/Uncoated) established the lowest values $(6.41 \mathrm{~g} / 100 \mathrm{~g} \mathrm{FW})$ as compared to the coated blueberries due to the ascorbic acid spontaneous oxidation. $(\mathrm{B} / \mathrm{CH})$ reported the highest content $(7.34 \mathrm{~g} / 100 \mathrm{~g}$ FW) 


\begin{tabular}{|l|c|l|l|l|}
\hline \multirow{2}{*}{ Storage (days) } & \multicolumn{4}{|l|}{ Firmness $\left(\mathrm{N} \mathrm{m}^{-\mathbf{1}}\right)$} \\
\cline { 2 - 5 } & $\mathbf{B} /$ uncoated & $\mathbf{B} / \mathbf{C H}$ & $\mathbf{B} / \mathbf{C H} / \mathbf{n a n o}^{\mathrm{a}} \mathrm{SiO}_{2}$ & $\mathrm{~B} / \mathbf{C H} /$ nano-TiO $_{2}$ \\
\hline 0 & $3.80 \pm 0.20^{\mathrm{b}}$ & $8.31 \pm 0.29^{\mathrm{ab}}$ & $7.95 \pm 0.55^{\mathrm{a}}$ & $3.37 \pm 0.28^{\mathrm{a}}$ \\
\hline 2 & $4.17 \pm 0.20^{\mathrm{c}}$ & $9.18 \pm 0.29^{\mathrm{bc}}$ & $9.26 \pm 0.55^{\mathrm{a}}$ & $6.92 \pm 0.29^{\mathrm{a}}$ \\
\hline 4 & $6.00 \pm 0.41^{\mathrm{d}}$ & $11.00 \pm 0.07^{\mathrm{c}}$ & $11.62 \pm 0.44^{\mathrm{a}}$ & $8.23 \pm 0.07^{\mathrm{ab}}$ \\
\hline 6 & $10.22 \pm 0.59^{\mathrm{d}}$ & $14.77 \pm 0.34^{\mathrm{bc}}$ & $13.21 \pm 0.54^{\mathrm{a}}$ & $8.40 \pm 0.34^{\mathrm{b}}$ \\
\hline 8 & $18.09 \pm 0.16^{\mathrm{a}}$ & $17.72 \pm 0.53^{\mathrm{a}}$ & $15.44 \pm 0.88^{\mathrm{a}}$ & $9.03 \pm 0.53^{\mathrm{a}}$ \\
\hline
\end{tabular}

Table 1. Effects of coating treatments on firmness. ${ }^{\star}$ Values within a column (lowercase) are significantly different $(p \geq 0.05)$. The values in parentheses indicate (SD \pm ) standard deviation.

followed by $\left(\mathrm{B} / \mathrm{CH} / \mathrm{Nano}-\mathrm{SiO}_{2}\right)(7.60 \mathrm{~g} / 100 \mathrm{~g} \mathrm{FW})$, while $\left(\mathrm{B} / \mathrm{CH} / \mathrm{Nano}-\mathrm{TiO}_{2}\right)$ recorded a little lower ascorbic acid value (7.88 g/100 g FW). Similarly, nanocoatings based on chitosan have reported a delay of ascorbic acid contents in treated blueberries ${ }^{9}$.

The $\mathrm{pH}$ values for (B/Uncoated) blueberries were slightly raised from 3.34 to 3.40 on the 6 th day then decrease to 3.24 at the end of the storage time, (Fig. $4 \mathrm{~b})$. $\left(\mathrm{CH} / \mathrm{Nano}-\mathrm{SiO}_{2}\right)$ coating films might report a good-quality fortification for $\mathrm{pH}$ value.

The effects of nano-material film coatings on soluble solid concentrations are shown in Fig. 4c. Soluble solid concentrations were increased during the whole storage time and ranged from 10.82 to $12.21 \%$ for (B/Uncoated) blueberry fruits and from 10.82 to $9.64 \%$ for coated blueberry fruits. Titratable acidity values for (B/Uncoated and coated blueberries) were found to be around (0.52-0.24\% citric acid) and (0.52-0.38\% citric acid), respectively, Fig. 4 d. (B/CH/Nano- $\left.\mathrm{TiO}_{2}\right)$ film established the highest titratable acidity values $(0.45 \%$ citric acid $)$.

Coated blueberries retained the ripening index (SSC/TAA ratio) obviously as shown in Fig. 4e. (B/Uncoated) samples recorded minimum increment between the 2 nd day $(23.38 \%)$ to the 6 th day $(33.17 \%)$ then the highest increment until the 8 th day $(51.61 \%)$ as compared to the other coated berries. $\left(\mathrm{B} / \mathrm{CH} / \mathrm{Nano}-\mathrm{TiO}_{2}\right)$ reported the lowest ripening ratio $(20.94 \%)$ followed by $(\mathrm{B} / \mathrm{CH})(25.51 \%)$, while $\left(\mathrm{B} / \mathrm{CH} / \mathrm{Nano}-\mathrm{SiO}_{2}\right)$ recorded a little high percentage $(26.78 \%)$.

Oxidation enzymes and anthocyanin contents. According to Fig. 5a, the results established high inactivation of peroxidase (POD) enzyme activities by $\left(\mathrm{B} / \mathrm{CH} / \mathrm{Nano}-\mathrm{TiO}_{2}\right)(20.39 \mathrm{U} / \mathrm{min} \mathrm{g})$ whereas $(\mathrm{B} / \mathrm{CH} /$ $\left.\mathrm{Nano}-\mathrm{SiO}_{2}\right)(21.06 \mathrm{U} / \mathrm{min} \mathrm{g})$ reported a little higher compared to $(\mathrm{B} /$ Uncoated) $(24.67 \mathrm{U} / \mathrm{min} \mathrm{g})$ samples.

The effect of various coating films on polyphenoloxidase (PPO) enzyme activity is shown in Fig. 5b. During $0-4$ days of storage at commercial temperature, all blueberry treatments except $\left(\mathrm{B} / \mathrm{CH} / \mathrm{Nano}-\mathrm{TiO}_{2}\right)(659.45 \mathrm{U} /$ min g) reported a gradual increase in (PPO) activity. A parallel finding was established on ready-to-eat cantaloupes stored in a chilling condition that nano-coatings films may limit the $\mathrm{O}_{2}$ concentration to explain the process of oxidation-reduction ${ }^{9}$. The results at the end of the storage period demonstrated the successful coating treatment was $(\mathrm{B} / \mathrm{CH})(558.03 \mathrm{U} / \mathrm{min} \mathrm{g})$ followed by $\left(\mathrm{B} / \mathrm{CH} / \mathrm{Nano}-\mathrm{SiO}_{2}\right)(551.63 \mathrm{U} / \mathrm{min} \mathrm{g})$.

The total anthocyanins in (B/Uncoated) samples increased compared to the other coated blueberries during the storage time passage. By the 8th day, $\left(\mathrm{B} / \mathrm{CH} / \mathrm{Nano}-\mathrm{SiO}_{2}\right)$ samples established the slightest change in (TAC) (105.19 cyanidin-3-O-glucoside $\mathrm{mg} / 100 \mathrm{~g} \mathrm{FW})$ compared to $\left(\mathrm{B} / \mathrm{CH} / \mathrm{Nano}-\mathrm{TiO}_{2}\right)$ and $(\mathrm{B} / \mathrm{CH})$ samples $(107.76$ and 112.34 cyanidin-3-O-glucoside $\mathrm{mg} / 100 \mathrm{~g} \mathrm{FW),} \mathrm{respectively,} \mathrm{Fig.} \mathrm{5c.}$

Microbial population measurements. Results on yeasts and molds populations of various coatings are shown in Fig. 6a. Blueberry samples treated $\left(\mathrm{B} / \mathrm{CH} / \mathrm{Nano}-\mathrm{SiO}_{2}\right)$ minimized the growth to values $<4 \log \mathrm{CFU} / \mathrm{g}$ against (B/Uncoated) and other coating films that might be associated with fungicide action of the (Nano$\left.\mathrm{SiO}_{2}\right)^{11}$. (B/CH) established (4.11 log CFU/g) when compared to (B/Uncoated) $(4.85 \log \mathrm{CFU} / \mathrm{g})$ during 8 days of storage due to the efficiency of antifungal activity of the chitosan component ${ }^{14}$.

As shown in Fig. 6b, mesophilic aerobic population reductions were effectively established for (B/CH/Nano$\mathrm{SiO}_{2}$ ) film as (3.73 log CFU/g). Moreover, $\left(\mathrm{B} / \mathrm{CH} / \mathrm{Nano}-\mathrm{TiO}_{2}\right)$ and $(\mathrm{B} / \mathrm{CH})$ recorded similar values $(3.83$ and $3.87 \log \mathrm{CFU} / \mathrm{g})$, respectively. In agreement with the population results, Alvarez et al., (30) established the strong effect of chitosan (2\%) on the mesophilic aerobic population of blueberry samples.

\section{Discussion}

Chitosan alone can control the fungus growth as Anthracnose (Colletotrichumacutatum), Alternaria (Alternaria spp.), and Botrytis (Botrytis cinerea). Chitosan can penetrate inside the fungus nuclei, cell membranes proteinaceous and intracellular constituents interferes that leads to its inhibition ${ }^{7}$. Moreover, nano-coatings developed blueberries shelf life by forming a physical barrier for respiration, dehydration, and senescence ${ }^{10,15}$.

Colour is a vital indicator of a blueberry sample's quality. The lightness loss can be due to the presence of nano-film coatings which can cause some surface changes ${ }^{9}$. The polyphenol oxidation reactions can be a reason for the colour decline ${ }^{16}$. Blueberries lose firmness during the postharvest storage, that leads to shelf-life limitation. Nano-coating with chitosan combination films reduces softening rates by reducing the metabolic activity as it performs as $\mathrm{O}_{2}$ and $\mathrm{CO}_{2}$ uptake barriers ${ }^{17}$.

Nano-coating with chitosan combination films might conserve the ascorbic acid contents against (B/ Uncoated) samples due to the oxidation-reduction on the permeable surface and exchange gas limitation ${ }^{18}$. 


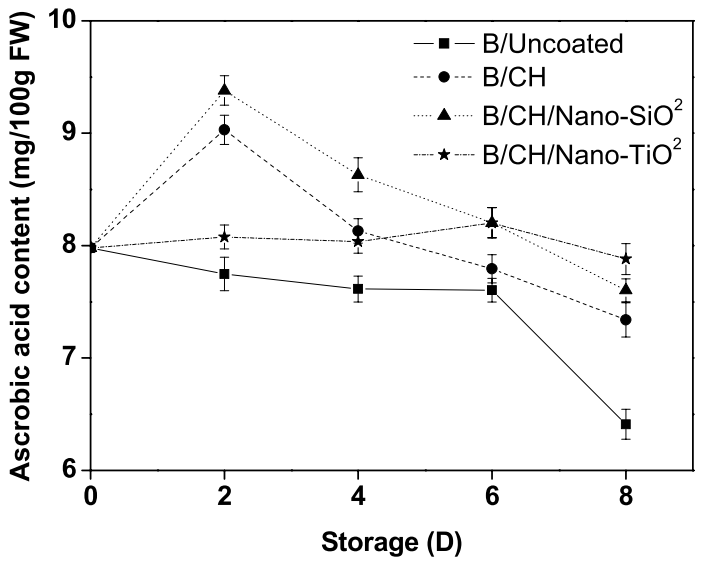

a

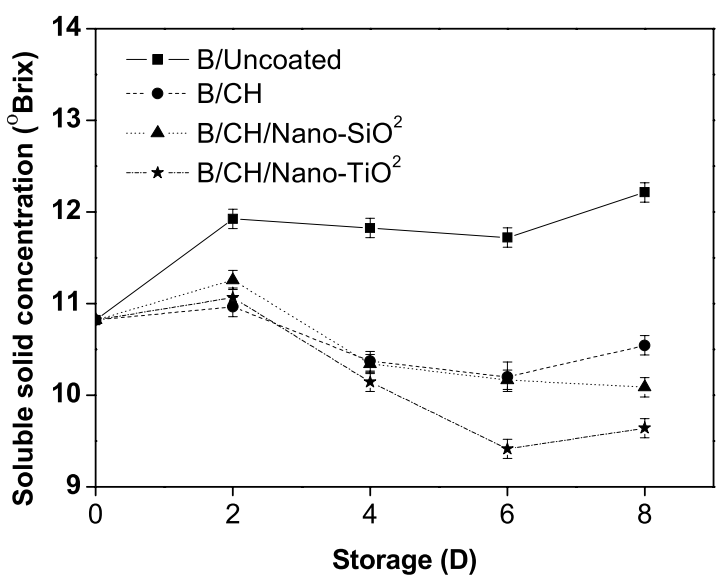

C

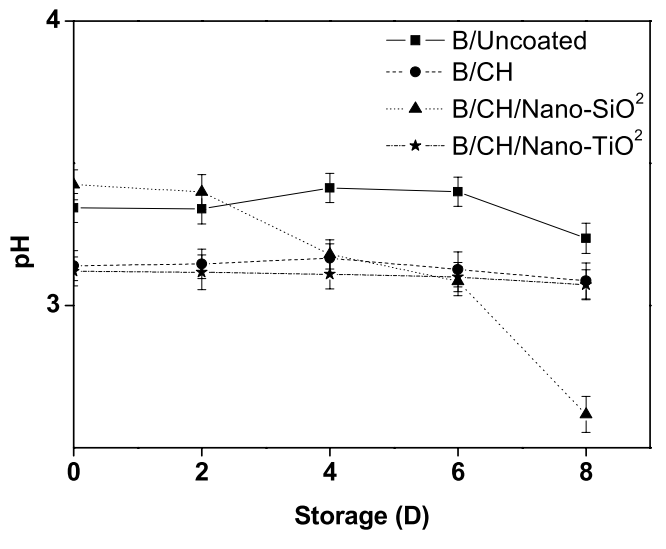

$\mathrm{b}$

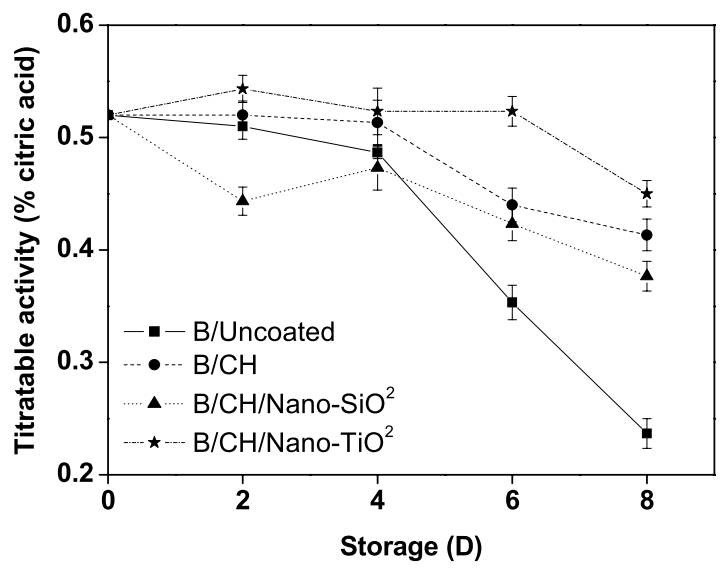

d

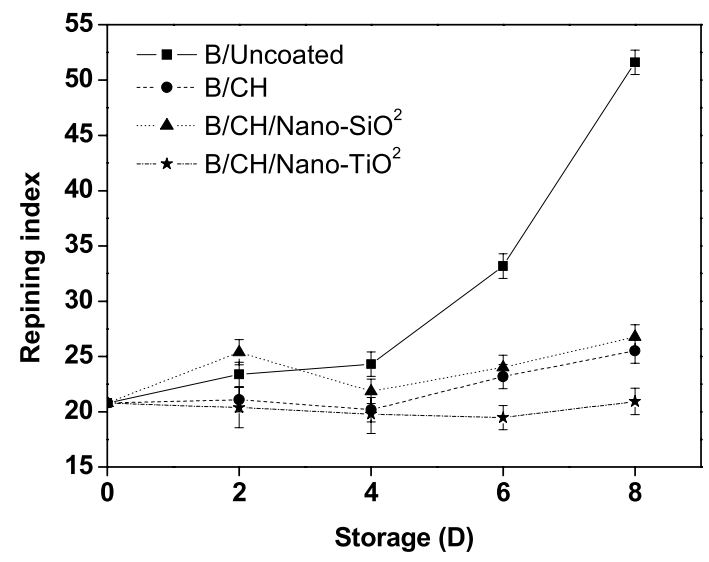

e

Figure 4. Phytochemical changes of ascorbic acid content (a), pH (b), soluble solid concentration (c), titratable acidity (d), and repining index (e) for coated blueberry samples.

Karolina et al., ${ }^{13}$ reported that the ascorbic acid reduction may be linked with the oxygen reduced diffusion and low respiration rate. The $\mathrm{pH}$ values decreases are in charge of fruit preservation against fungal and bacterial growth by using edible coating films ${ }^{3}$. The soluble solid concentration of (B/Uncoated) blueberries were higher than those of coated samples due to the maturation and over ripening. The increase of soluble solid concentration is probably associated with the moisture loss, as blueberries were harvested fully ripe ${ }^{19}$. Karolina et al. ${ }^{13}$, reported that coatings may change the atmosphere around fruits, that as a result can reduce metabolism rates. Citric acid is the major organic acid in the blueberries juice that can refer to the fruit ripens, while the lowest value for (B/ Uncoated) samples was due to the fungal population ${ }^{20}$. In a word, titratable acidity values were positively influenced by delaying maturation with the presence of coating films during the storage period. These results could 


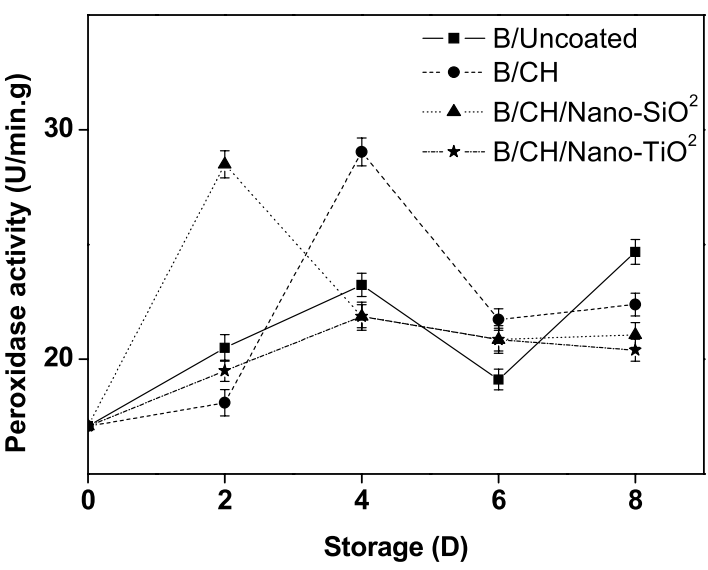

a

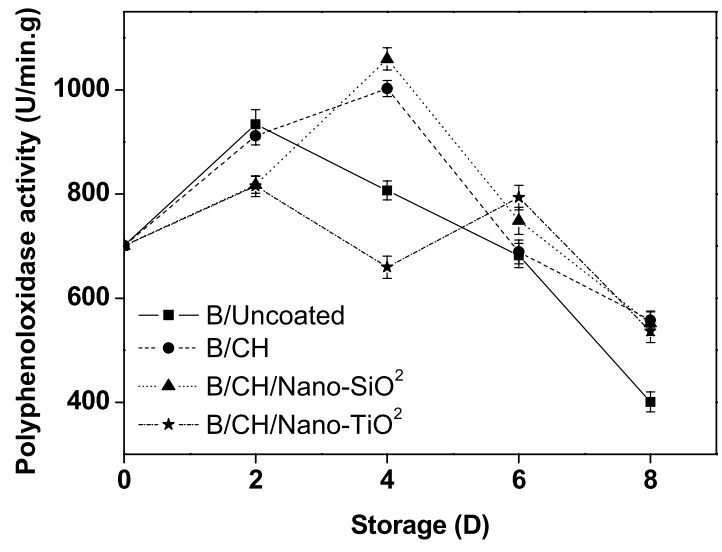

b

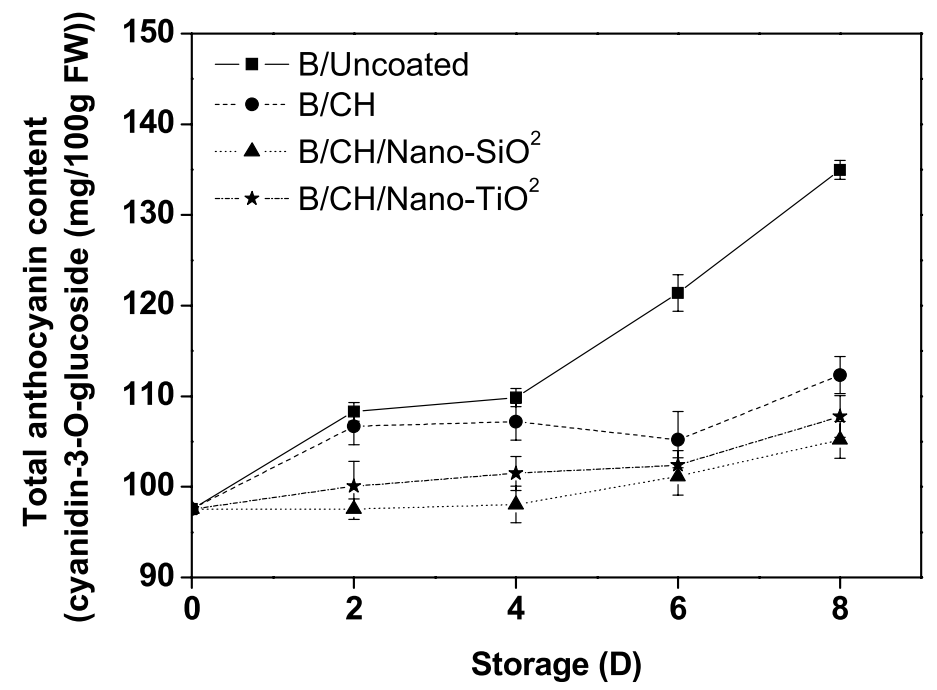

C

Figure 5. Effects of coating treatments on oxidation enzymes (a,b) and anthocyanin contents (c).

report that the nano-material and chitosan combinations is acceptable for the gradual maturation ${ }^{3}$. Repining index is a vital quality parameter which evaluates the acidity and sweetness of fruits. Coating films especially with chitosan might create a modification of the interior atmosphere in coated several fruits. The performance was justified to the correlation between soluble solid concentration/titratable acidity ratio as any reductions in titratable acidity values would produce increases in the repining index, that will result in a sugary taste to the treated samples ${ }^{21}$. Consequently, nano-materials were effective in blueberry ripening delay.

Peroxidase enzyme activity (POD and PPO) is essential in diphenols reduction. The efficiency of the activity results depends on quite a lot of factors such as the ripening stage, storage, treatment and duration applied ${ }^{22}$. $\operatorname{Rok}^{9}$, established that nano-coating materials may clarify the oxidation-reduction due to the oxygen rate decrease. Guohua et al..$^{10}$, established that (POD and PPO) activity reductions might be due to blueberries abiotic stress. Anthocyanin pigments are in charge of the blue and red colour in the horticultural and any changes in values could be due to the phenolics catalyzed oxidation by (POD,PPO) and continuous biosynthesis during the storage $^{6,23}$.

The blueberry's quality is influenced by microorganisms such as yeasts and fungal infections. The combination of (chitosan $+\mathrm{Nano}-\mathrm{SiO}_{2}$ ) can result in enhancing the antifungal capacity and limit the microbial population to extend the fresh blueberry shelf life at commercial temperature.

As a result, the optical estimation confirmed that (B/Uncoated) fruits had widespread microbial growth on the surface at the end of the storage period. The chitosan-coating film with or even without nano-materials inhibited the microbial population.

In conclusions, composite nano-films are eco-friendly, performed with chitosan have been enhanced physical, mechanical, phytochemical, and nutritional components with microbial population inhibition on fresh blueberry fruits during commercial storage. The results established that using nano-material coating films can extend the shelf-life, delay ripening, and control spoilage such as yeasts, mould populations, and mesophilic aerobic counts. Blueberry fruits influenced by chitosan film alone achieved better lightness for colour index. 


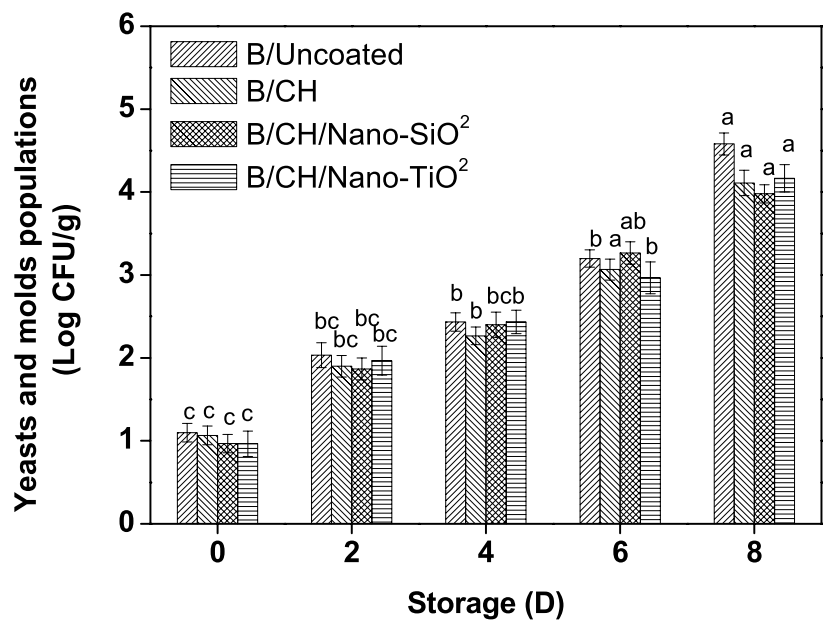

a

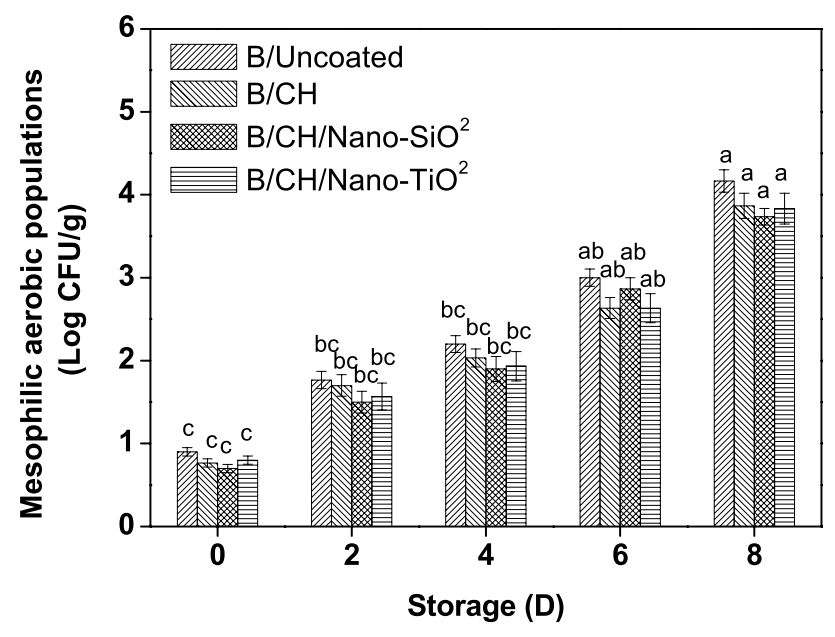

b

Figure 6. Microbial population measurements on coated on blueberries.

Formation semi-films by nano-materials especially with $\left(\mathrm{SiO}_{2}-\mathrm{TiO}_{2}\right)$ is needed for nanotechnology application and preservation industries for consumable vegetables and fruits.

\section{Materials and methods}

Materials and fruit sample. Chitosan (85\%), nano-(silicon/titanium dioxides $15 \mathrm{~nm}$ ) and glycerol, acetic acid were from (Sigma, USA). Four Kg of fresh blueberries (Vacciniumashei L.) in relative humidity (80-90\%) were procured from a local grocery store, transported to the laboratory of the college of science, Taif University.

Coating films preparations. Chitosan film $1 \%(\mathrm{~B} / \mathrm{CH})$ was arranged by blending acetic acid and glycerol. The coating film was stirred over night at $300 \mathrm{rpm}$ and centrifuged at $4{ }^{\circ} \mathrm{C}$ for $30 \mathrm{~min}$. Chitosan-nano-silicon dioxide $\left(\mathrm{B} / \mathrm{CH} / \mathrm{Nano}-\mathrm{SiO}_{2}\right)$ and chitosan-nano-titanium dioxide $\left(\mathrm{B} / \mathrm{CH} / \mathrm{Nano}-\mathrm{TiO}_{2}\right)$ films were arranged by adding $1 \%$ of $\mathrm{Nano}-\mathrm{SiO}_{2}$ and $\mathrm{TiO}_{2}$ to the chitosan solution, respectively. While, (B/Uncoated) was the treated samples with deionized water.

Fruit treatments and storage. The uniform blueberries were selected in size, colour, weight, relative humidity in-between 80 and $90 \%$, and without any sign of optical physical damage or even microbial contaminations from an orchard in Harbin, Heilongiiang Province, China. The bulk was divided into four quarters according to the experimental design and stored into holy small boxes. Blueberries were dipped into various coating films, dried, and stored at the commercial temperature $\left(27 \pm 0.5^{\circ} \mathrm{C}\right)$ for up to $(8$ days $)$ and analyzed on days 2,4 , 6 , and 8 for all the postharvest quality parameters.

Physical and mechanical parameters. Each blueberry group was regularly weighed using a scale with an accuracy of $(0.01 \mathrm{~g})$ and calculated as accumulated weight loss and decay rate as a percentage per unit storage time, Eqs. (1) and (2) ${ }^{13}$. 


$$
\text { Weight } \operatorname{loss}(\%)=\left(1-\frac{w_{f}}{w_{i}}\right) \times 100
$$

where $w_{i}$ is the initial blueberry weight and $w_{f}$ is the blueberry weight during the storage.

$$
\text { Decay Rate }(\%)=\left(1-\frac{V_{t}}{V_{o}}\right) \times 100
$$

where $V_{t}$ is the blueberry apparent volume at a certain degree of dryness after time $t$ and $V_{o}$ is the raw blueberry apparent volume.

Blueberries colour index such as $\left(L^{*}, a^{*}\right.$, and $\left.b^{*}\right)$ were evaluated by using (CR-400 Chroma Meter, USA) with an $8 \mathrm{~mm}$ aperture ${ }^{24}$. Firmness texture analysis for various coating treatments was achieved by using (TAXT Plus, UK) with $13 \mathrm{~mm}$ probe height, a distance of $3 \mathrm{~mm}, 50 \mathrm{~kg}$ load transducer and pretest speed of $(2 \mathrm{~mm} / \mathrm{s})$ and test speeds of $(1 \mathrm{~mm} / \mathrm{s})$ with an automatic trigger $(5 \mathrm{~g})^{10}$. Firmness was expressed as newton per meter $\left(\mathrm{N} \mathrm{m}^{-1}\right)$ by determination of fifteen pieces per replicate.

Determination of phytochemical contents. The various coated blueberries for all treatments (50 g) were blended for the determination of phytochemical contents. Ascorbic acid content was detected by the oxalic acid titration method explained by Rok and expressed as $(\mathrm{mg} / 100 \mathrm{~g} \mathrm{FW})^{9}$. $\mathrm{pH}$ measurements are essential indicators for the microbial growth which might cause the spoilage. The $\mathrm{pH}$ values were examined using a $\mathrm{pH}$ meter (320, Toledo, China). After berry juice homogenization, $\mathrm{pH}$ readings were evaluated by the direct electrode inundation ${ }^{3}$. Juice from the blueberry samples was used for soluble solid concentration ( $\left.{ }^{\circ} \mathrm{Brix}\right)$ by using a refractometer (Model 30PX, USA). Titratable acidity was detected according to 942.15 AOAC methods ${ }^{25}$, by determining $0.1 \mathrm{~mol} \mathrm{~L}^{-1}$ sodium hydroxide until $\mathrm{pH}$ equals (8.1). Results were calculated as a percent (grams of citric acid equivalent/100 g), Eq. (3).

$$
\text { Titratable Acidity }(\%)=\frac{0.1 \mathrm{~N} \mathrm{NaoH} \text { used } \times 0.0064}{m l \text { of juice used }} \times 100
$$

The Repining index was applied by the quotient between both titratable acidity (TAA) and soluble solid concentration (TSS), Eq. $(4)^{10}$.

$$
\text { Ripening Index }=\frac{T S S}{T A A}
$$

Determination of peroxidase and polyphenoloxidase enzymes and anthocyanin contents. Approximately $5 \mathrm{~g}$ of coated blueberry samples were weighed, homogenized in $100 \mathrm{~mL}$ of sodium phosphate buffer $(100 \mathrm{mM}, \mathrm{pH} 7.0)$, centrifuged at $16,000 \mathrm{r} / \mathrm{min}$, filtered, and stored at $-18^{\circ} \mathrm{C}$ for polyphenoloxidase enzyme determination. $2.2 \mathrm{~mol} / \mathrm{L}$ sodium phosphate buffer, and $(0.5 \mathrm{~mL})$ of $0.175 \mathrm{~mol} / \mathrm{L}$ catechol solution were added to gain the ionically bound enzymes for the extracts and detected at $(410 \mathrm{~nm})^{11}$. Peroxidase enzyme was determined by blending $5 \mathrm{~g}$ of coated blueberries with $(3 \mathrm{~mL}) 0.1 \mathrm{~mol} / \mathrm{L}$ pyrocatechol solution, centrifuged at $16,000 \mathrm{r} / \mathrm{min}$, and filtrated with a detection at $(460 \mathrm{~nm})^{26}$. Total anthocyanin contents (TAC) in blueberry samples were evaluated by using a spectrum spectrophotometer $(754 \mathrm{PC}$, China) at $(520 \mathrm{~nm})$. Results were expressed as cyanidin-3-O-glucoside equivalents (mg/100 g FW $)^{27}$.

Microbial population studies. Blueberries microbial populations were examined by placing $15 \mathrm{~g}$ of various coatedsamples in a sterile plastic bag with $85 \mathrm{~mL}$ of the peptone water and were homogenized by using a Stomacher (400 Circulator, United Kingdom). Serial dilutions $\left(10^{-1}, 10^{-2}\right.$, and $\left.10^{-3}\right)$ were made until the surface spreading on the selective media ( $3 \mathrm{M} 212$ petrifilms) $)^{28}$. Mesophilic aerobic populations were incubated at $37^{\circ} \mathrm{C}$ for 2 days, while yeasts and molds populations were incubated at $25^{\circ} \mathrm{C}$ for 5 days. Results were calculated as $\log$ $\mathrm{CFU} / \mathrm{g}$ in three sample containers with three replicate counts of each treatment.

Statistical analysis. All date results were expressed as (mean \pm SD) with three replicates for each value and analyzed by SPSS (26.00 software), while the mean separation was significantly $(p \leq 0.05)$ by the Duncan's multiple tests.

Received: 6 October 2020; Accepted: 9 December 2020

Published online: 08 January 2021

\section{References}

1. Mannozzi, C. et al. Study on the efficacy of edible coatings on quality of blueberry fruits during shelf-life. LWT Food Sci. Technol. 85, 440-444 (2016).

2. Xinyao, J. et al. Effect of in vitro-simulated gastrointestinal digestion on the stability and antioxidant activity of blueberry polyphenols and their cellular antioxidant activity towards HepG2 cells. Int. J. Food Sci. Technol. 53, 61-71 (2017).

3. Vieira, J. M. et al. Effect of chitosan-Aloe vera coating on postharvest quality of blueberry (Vaccinium corymbosum) fruit. Postharvest Biol. Technol. 116, 88-97 (2016).

4. Abugoch, L. et al. Shelf-life of fresh blueberries coating with quinoa protein/chitosan/sunflower oil edible film. J. Sci. Food Agric. 96, 619-626 (2016). 
5. Giuggioli, N. R., Girgenti, V. \& Peano, C. Qualitative performance and consumer acceptability of starch films for the blueberry modified atmosphere packaging storage. Pol. J. Food Nutr. Sci. 67, 129-136 (2017).

6. Duan, J., Wu, R., Strik, B. \& Zhao, Y. Effect of edible coatings of fresh blueberries (Duke and Elliott) under commercial storage conditions. Postharvest Biol. Technol. 59, 71-79 (2011).

7. Wang, Y. et al. Changes in membrane lipid metabolism accompany pitting in blueberry during refrigeration and subsequent storage at room temperature. Front. Plant Sci. 10, 829 (2019).

8. Zhang, L., Yan, Z., Hanson, E. J. \& Ryser, E. T. Efficacy of chlorine dioxide gas and freezing rate on the microbiological quality of frozen blueberries. J. Food Control 47, 114-119 (2015).

9. Rok, E. Application of nano-coating and chitosan combination films on cantaloupe preservation. Pak. J. Biol. Sci. 23, 1-7 (2020).

10. Guohua, Q., Zhigang, X., Wenxin, D. \& Ahmed, R. Effect of chitosan/nano-titanium dioxide/thymol and tween films on readyto-eat cantaloupe fruit quality. Coatings 9(828), 1-10 (2019).

11. Xiaohong, K. et al. Effect of abscisic acid (ABA) and chitosan/nano-silica/sodium alginate composite film on the color development and quality of postharvest Chinese winter jujube (Zizyphus jujuba Mill cv. Dongzao). Food Chem. 270, 385-394 (2019).

12. Alina, S. \& Markus, S. Packaging concepts for ready-to-eat food: recent progress. J. Packag. Technol. Res. 1, 113-126 (2017).

13. Karolina, K. et al. Effect of Pullulan coating on postharvest quality and shelf-life of highbush blueberry (Vaccinium corymbosum L.). Materials 10(965), 1-17 (2017).

14. Qiu, M. et al. Effect of chitosan and its derivatives as antifungal and preservative agents on postharvest green asparagus. Food Chem. 155, 105-111 (2014).

15. Jahanzaib, Q. et al. Effect of Aloe vera Gel, chitosan and sodium alginate based edible coatings on postharvest quality of refrigerated strawberry fruits of cv. Chandler. J. Hortic. Sci. Technol. 1(1), 8-16 (2018).

16. Reque, P. M. et al. Cold storage of blueberry (Vaccinium spp.) fruits and juice: anthocyanin stability and antioxidant activity. J. Food Compos. Anal. 33(1), 111-116 (2014).

17. Sogvar, O. B., Saba, M. K. \& Emamifar, A. Aloe vera and ascorbic acid coatings maintain postharvest quality and reduce microbial load of strawberry fruit. Postharvest Biol. Technol. 114, 29-35 (2016).

18. Sun, Y. et al. Comparative phytochemical profiles and antioxidant enzyme activity analyses of the southern Highbush blueberry (Vaccinium corymbosum) at different developmental stages. Molecules 23, 1-14 (2018).

19. Paniagua, A., East, A., Hindmarsh, J. \& Heyes, J. Moisture loss is the major cause of firmness change during postharvest storage of blueberry. Postharvest Biol. Technol. 79, 13-19 (2013).

20. Benítez, S., Achaerandio, I., Sepulcre, F. \& Pujolà, M. Aloe vera based edible coatings improve the quality of minimally processed 'Hayward' kiwifruit. Postharvest Biol. Technol. 81(29-36), 2013 (2013).

21. Petriccione, M. et al. Effect of chitosan coating on the postharvest quality and antioxidant enzyme system response of strawberry fruit during cold storage. Foods 4, 501-523 (2015).

22. Siddiq, M. \& Dolan, K. D. Characterization of polyphenoloxidase from blueberry (Vaccinium corymbosum L.). Food Chem. 218, 216-220 (2017).

23. Nunes, M. C. N., Brecht, J. K., Morais, A. M. \& Sargent, S. A. Possible influences of water loss and polyphenol oxidase activity on anthocyanin content and discolouration in fresh ripe strawberry during storage at $1{ }^{\circ} \mathrm{C}$. J. Food Sci. 70(1), 116121 (2005).

24. Ícaro, P. et al. Biodegradable coatings on blueberries postharvest conservation refrigerated in a modified atmosphere. J. Exp. Agric. Int. 20(4), 1-11 (2018)

25. AOAC. Official Methods of Analysis of the Association of Official Analytical Chemists (AOAC) International 16th edn. (AOAC International, Washington, 1997).

26. Sonja, V., Biljana, K., Branka, S. \& Flavia, N. Senescence- and drought-related changes in peroxidase and superoxide dismutase isoforms in leaves of Ramonda serbica. J. Exp. Bot. 57(8), 1759-1768 (2006).

27. Hengjun, J., Zhimin, S., Ruixiu, J., Xiangyang, W. \& Jianying, H. Effect of chitosan as an antifungal and preservative agent on postharvest blueberry. J. Food Qual. 39, 516-523 (2016).

28. Pei, C., Mohd, A., Roselina, K. \& Zainal, A. Microbiological stability and quality of pulsed light treated cantaloupe (Cucumis melo L. reticulatus cv. Glamour) based on cut type and light fluence. J. Food Sci. Technol. 53(4), 1798-1810 (2016).

\section{Acknowledgements}

Taif University Researchers Supporting Project Number (TURSP-2020/140), Taif University, Taif, Saudi Arabia. This research was funded by the Deanship of Scientific Research at Princess Nourah Bint Abdulrahman University through the Fast-track Research Funding Program.

\section{Author contributions}

Conceptualization, supervision: Y.L. Writing-original draft preparation, Experimental work: S.R. Validation, supervision: F.J. Experimental work: X.N. Experimental work: J.X. Formal analysis, Editing language: A.E. Investigation: M.A. Resources: N.B. Statistical analysis: M.H.

\section{Competing interests}

The authors declare no competing interests.

\section{Additional information}

Correspondence and requests for materials should be addressed to Y.L., S.R. or F.J.

Reprints and permissions information is available at www.nature.com/reprints.

Publisher's note Springer Nature remains neutral with regard to jurisdictional claims in published maps and institutional affiliations. 
(c) (i) Open Access This article is licensed under a Creative Commons Attribution 4.0 International cc) License, which permits use, sharing, adaptation, distribution and reproduction in any medium or format, as long as you give appropriate credit to the original author(s) and the source, provide a link to the Creative Commons licence, and indicate if changes were made. The images or other third party material in this article are included in the article's Creative Commons licence, unless indicated otherwise in a credit line to the material. If material is not included in the article's Creative Commons licence and your intended use is not permitted by statutory regulation or exceeds the permitted use, you will need to obtain permission directly from the copyright holder. To view a copy of this licence, visit http://creativecommons.org/licenses/by/4.0/.

(C) Crown 2021 